\title{
KUALITAS PELAYANAN PUBLIK PADA KANTOR CAMAT TENAYAN RAYA KOTA PEKANBARU
}

\author{
Widia Astuti, Irawati, Ruslihardy \\ Universitas Lancang Kuning \\ Email : widiaastuti@unilak.ac.id
}

\begin{abstract}
Keberhasilan pembangunan daerah tentunya dipengaruhi oleh administrasi yang dijalankan oleh daerah tersebut, dimana pelaksanaanya sangat dipengaruhi oleh kemampuan aparatur dalam melaksanakan tugasnya. Peran aparatur pemerintah lebih cenderung sebagai agen pembaharuan dan pemberdayaan masyarakat tersebut. Oleh karena itu, fungsi pengaturan dan pengendalian yang dilakukan oleh aparatur pemerintah adalah perumusan dan pelaksanaan kebijakan yang berfungsi sebagai motivator dan fasilitator guna tercapainya tujuan pembangunan yang adil dan merata disegala bidang.Kecamatan salah satu ujung tombak pelayanan public harus memberikan pelayanan yang optimal dan berkualitas sehinggah peran kecamatan sebagai salag satu pelayanan masyarakat dapat berdaya guna dan berhasil guna.
\end{abstract}

Kata kunci : Kualitas,pelayanan public

\section{Abstract}

The success of regional development by the government run by these areas, where the implementation is greatly influenced by the ability of the apparatus in performing their duties. The role of the government apparatus is mostly used as a means of renewal and empowerment of the community. Therefore, the basic functions and control performed by the government apparatus is the formulation and implementation of policies that function as a motivator and facilitator for the achievement of fair and equitable development goals in all fields. Conservation of one of the spearheads of public services must provide optimal service and quality sehinggah the role of kecamatan as a salag of one community service can be efficient and effective.

Keywords: Quality, public service

\section{PENDAHULUAN}

Perkembangan kehidupan masyarakat membawa tuntutan masyarakatpun semakin meningkat. Hal tersebut terkait dengan banyaknya permasalahan yang belum sepenuhnya teratasi. Dari sisi internal, berbagai faktor seperti demokrasi, desentralisasi dan internal birokrasi itu sendiri, masih berdampak pada tingkat kompleksitas permasalahan dan dalam upaya mencari solusi lima tahun ke depan. Sedangkan dari sisi eksternal, faktor globalisasi dan revolusi teknologi informasi juga akan kuat berpengaruh terhadap pencarian alternatif-alternatif kebijakan dalam bidang aparatur negara.

Dari sisi internal, faktor demokratisasi dan desentralisasi telah membawa dampak pada proses pengambilan keputusan kebijakan publik. Dampak tersebut terkait dengan, makin meningkatnya tuntutan akan partisipasi masyarakat dalam kebijakan publik; meningkatnya tuntutan penerapan prinsip-prinsip tata kepemerintahan yang baik antara lain transparansi, akuntabilitas dan kualitas kinerja publik serta taat pada hukum; meningkatnya tuntutan dalam penyerahan tanggung jawab, kewenangan dan pengambilan keputusan.

Demikian pula, secara khusus dari sisi internal birokrasi itu sendiri, berbagai permasalahan masih banyak dihadapi. Permasalahan tersebut antara lain adalah: pelanggaran disiplin, penyalahgunaan kewenangan dan penyimpangan yang tinggi; rendahnya kinerja sumber daya aparatur; sistem kelembagaan (organisasi) dan ketatalaksanaan (manajemen) pemerintahan yang belum memadai; rendahnya efisiensi dan efektifitas kerja; 
rendahnya kualitas pelayanan umum; rendahnya kesejahteraan PNS; dan banyaknya peraturan perundangundangan yang sudah tidak sesuai dengan perkembangan keadaan dan tuntutan pembangunan.

Sedangkan dari sisi eksternal, faktor globalisasi dan revolusi teknologi informasi merupakan tantangan sendiri dalam upaya menciptakan pemerintahan yang bersih dan berwibawa. Hal tersebut terkait dengan makin meningkatnya ketidakpastian akibat perubahan faktor lingkungan politik, ekonomi, dan sosial yang terjadi dengan cepat; makin derasnya arus informasi dari manca negara yang dapat menimbulkan infiltrasi budaya dan terjadinya kesenjangan informasi dalam masyarakat (digital divide). Perubahanperubahan ini, membutuhkan aparatur negara yang memiliki kemampuan pengetahuan dan keterampilan yang handal untuk melakukan antisipasi, menggali potensi dan cara baru dalam menghadapi tuntutan perubahan. Di samping itu aparatur negara harus mampu meningkatkan daya saing, dengan melakukan aliansi strategis untuk menjaga keutuhan bangsa.

Pelaksanaan reformasi birokrasi saat ini masih dirasakan kurang berjalan sesuai dengan tuntutan reformasi, hal tersebut terkait dengan tingginya kompleksitas permasalahan dalam upaya mencari solusi perbaikan. Masih tingginya tingkat penyalahgunaan wewenang, banyaknya praktek KKN, dan masih lemahnya pengawasan terhadap kinerja aparatur negara merupakan cerminan dari kondisi kinerja birokrasi yang masih jauh dari harapan. Oleh karena itu, dibutuhkan suatu upaya yang lebih komprehensif dan terintegrasi dalam upaya mendorong peningkatan kinerja birokrasi aparatur negara. Tuntutan untuk menciptakan pemerintahan yang bersih dan akuntabel merupakan amanah reformasi dan tuntutan seluruh rakyat Indonesia.

Keberhasilan pembangunan daerah tentunya dipengaruhi oleh administrasi yang dijalankan oleh daerah tersebut, dimana pelaksanaanya sangat dipengaruhi oleh kemampuan aparatur dalam melaksanakan tugasnya. Peran aparatur pemerintah lebih cenderung sebagai agen pembaharuan dan pemberdayaan masyarakat tersebut. Oleh karena itu, fungsi pengaturan dan pengendalian yang dilakukan oleh aparatur pemerintah adalah perumusan dan pelaksanaan kebijakan yang berfungsi sebagai motivator dan fasilitator guna tercapainya tujuan pembangunan yang adil dan merata disegala bidang.

Pemerintah dengan menggulirkan kebijakan pemberian otonomi daerah Undang - Undang Nomor 32 Tahun 2004 tentang pemerintah daerah . wilayah kabupaten / kota merupakan sistem pemerintahan negara yang keberadaannya sangat dekat dengan masyarakat yang diharapkan mampu memberikan pemberdayaan partisipasi dalam pembangunan . otonomi daerah sebagai manifestasi dari desentralisasi teritorial telah banyak dibicarakan baik dikalangan pakar, elit pemerintahan, praktisi pemerintahan baik pusat maupun daerah serta kalangan pers dan media massa . hal ini dikarenakan masalah desentralisasi dan otonomi daerah bukan hanya merupakan masalah administrasi belaka., melainkan juga masalah politik , ekonomi , pembangunan dan kemasyarakatan yang mengharapkan adanya perbaikan kualitas pelayanan terhadap publik dimana bisa menggembalikan kepercayaan pemerintah kepada masyarakat.

Salah satu organisasi publik yang harus memberikan pelayanan kepada masyarakat adalah kecamatan. Berdasarkan Undang- Undang Nomor 32 Tahun 2004 kecamatan adalah organisasi pemerintah yang di bentuk di wilayah kota dengan perda dan berpedoman kepada peraturan pemerintah dan melaksanakan sebagian pelimpahan tugas dari walikota/bupati untuk menangani sebagian urusan otonomi daerah.

Program kerja di lakukan oleh para birokrat di kecamatan memerlukan dukungan dari masyarakat itu sendiri terutana untuk menciptakan kondisi pemerintahan yang bersih ( Clean Governance ) dan pemerintahan yang baik ( Good Governance ). Oleh karena itu, masyarakat dapat di jadikan sebagai kontrol dalam me ngamati kinerja para birokrat. Masyarakat bukan lagi sebagai objek kekuasaan birokrat melainkan sebagai mitra kerja dalam pencapaian tujuan pemerintah yaitu keadilan dan kesejahteraan.

Pelayanan merupakan tugas utama yang hakiki dari sosok aparatur, sebagai abdi negara dan abdi masyarakat. Tugas ini telah dijelaskan dalam pembukaan UUD 1945 alinea ke empat, yang meliputi 4 ( 
empat ) aspek bagi pelayanan pokok aparatur terhadap masyarakat, yaitu melindungi segenap bangsa indonesia dan seluruh tumpah darah indonesia, memajukan kesejahteraan umum, mencerdaskan kehidupan bangsa dan melaksanakan ketertiban dunia yang berdasarkan kemerdekaan, perdamaian abadi dan keadilan sosial.

Kecamatan Tenayan Raya terdiri dari empat kelurahan,yaitu kelurahan sail,rejosari,kulim dan tangkerang selatan.

Ada beberapa alasan yang melatar belakangi dipilihnya kecamatan Tenayan Raya sebagai lokasi penelitian yaitu :

1. kecamatan tenayan raya adalah merupakan kecamatan yang terbesar ke 3 dari 12 kecamatan yang ada di kota peknbaru yang memiliki luas $171,27 \mathrm{~km} 2$ yang berpenduduk 136.716 jiwa.

2. kecamatan tenayan raya berada pada jalan lintas timur sumatera.

3. kecamatan tenayan raya dari 12 kecamatan yang ada di kota pekanbaru dijadikan sebagai kawasan industry tenayan raya dengan luas $1.550 \mathrm{Ha}$ yang terletak $14 \mathrm{Km}$ dari pusat kota.

Bentuk pelayanan di kantor camat tenayan raya kota pekanbaru adalah sebagai berikut

Tabel 1.1.bentuk pelayanan public 2015

\begin{tabular}{|c|c|l|l|l|}
\hline No & Bentuk pelayanan & target & realisasi & Persentase \\
\hline 1 & Pembuatan KTP & 740 & 612 & 80 \\
2 & Pembuatan kartu keluarga & 400 & 351 & 85 \\
3 & Surat keterangan kelahiran & 52 & 38 & 60 \\
4 & Rekomendasi SITU & 10 & 7 & 70 \\
5 & SKGR & 200 & 165 & 80 \\
6 & Surat gangguan Ho & 20 & 15 & 83 \\
\hline
\end{tabular}

Penerapan dan penilaian kualitas pelayanan dapat menjadikan cerminan untuk mewujudkan kepuasan masyarakat di kelurahan rejosari kecamatan tenanyan raya kota pekanbaru sebagai salah satu tujuan untuk menciptakan pemerintahan yang baik adalah pemberian pelayanan yang optimal pada masyarakat sehingga masyarakat puas dan percaya kepada kinerja birokrat. Oleh karena itu, berdasarkan UNDP menyatakan bahwa pemerintahan yang baik adalah harus menaati aturan hukum yang ada dan bersifat transparansi kepada masyarakat.

Dari hasil pra survey yang penulis lakukan terlihat bahwa pelaksanaan penilaian dan peningkatan kualitas dalam pelayananan publik di Kantor camat tenayan raya masih ada beberapa permaslahan yang terjadi mulai dari prosedur pelayanan yang berbelit-belit sampai soal sikap aparat yang tidak menyengkan. seperti adanya sikap aparatur kelurahan yang masih belum mempunyai etika dalam pemberian pelayanan kepada masyarakat dengan sikap kurang ramah dan mimik wajah yang kurang bersahabat, selain itu, masih kurang disiplinya aparat kecamatan yang datang ke kantor juga mempengaruhi pemberian pelayanan kepada masyarakat yang dapat mengakibatkan pelayanan tidak tepat waktu dan bertele- tele. Atas dasar itulah Tim ingin melakukan Pengabdian pada masyarakat dengan judul Kualitas Pelayanan Publik Dikantor Camat Tenayan Raya Kota Pekanbaru.

\section{METODE}

\section{A.Pendekatan Penelitian}

Pendekatan yang digunakan dalam penelitian ini adalah pendekatan kualitatif,yaitu bermaksud untuk memperoleh gambaran yang mendalam tentang bagaimana kualitas pelayanan pelayanan public pada kantor camat tenayan raya kota Pekanbaru. 


\section{B.Lokasi Penelitian}

Penelitian dilakukan dikantor Camat Tenayan raya Kota Pekanbaru.

\section{Sumber dan Jenis Data}

Sumber dan jenis data dalam penelitian ini adalah sebagai berikut :

1. Data Primer

Data primer adalah data yang dikumpulkan langsung dari informan yang terpilih dalam penelitian ini.Adapun penentuan informan dalam penelitian ini,peneliti merujuk pada criteria yang disampaikan Spradley (dalam Iskandar:116). Tehnik penarikan sampel yang digunakan adalah dengan mengunakan tehnik sensus untuk aparat kecamatan dan tehnik aksidental untuk keterangan maupun jawaban dari masyarakat yang mendapat layanan di kecamatan tenayan raya kota pekanbaru.

Tabel 1. Populasi dan sampel kualitas pelayanan public di kantor camat kota Pekanbaru.

\begin{tabular}{|c|cc|c|}
\hline No & Populasi & Sub populasi & Sampel \\
\hline $\mathbf{1}$ & Sekretaris Camat & 1 & 1 \\
\hline $\mathbf{2}$ & Kasi & 3 & 3 \\
\hline $\mathbf{3}$ & Staf & 23 & 23 \\
\hline $\mathbf{4}$ & Masyarakat & & 20 \\
\hline Jumlah & & 47 & 47 \\
\hline
\end{tabular}

Sumber :Kantor camat,2016

\section{Data Sekunder}

Data sekunder diperoleh dari literature-literatur,media cetak,ataupun media elektronik, seperti profil kecamatan dll.

\section{Tehnik Pengumpulan Data}

Untuk menghimpun data yang diperlukan,maka dipergunakan tehnik pengumpulan data observasi, wawancara, dan angket.

\section{Analisa Data Penelitian}

Data yang telah terkumpul berdasarkan jenis dan bentuk data, untuk selanjutnya data tersebut dianalisis secara deskriftif kualitatif.

\section{HASIL DAN PEMBAHASAN}

Data dalam penelitian ini diperoleh dari hasil menyebarkan kuestioner kepada 47 sample, yang terdiri dari 27 aparatur kantor camat tenayan raya kota pekanbaru dan 20 masyarakat yang berada di kecamatan tenayan raya.Dimana responden menjawab pertanyaan yang diajukan dalam kuestioner.

Dengan indicator sebagai berikut :

1. Transparansi

2. Akuntabilitas

3. Kondisional

4. Partisipatif

5. Kesamaan Hak

6. Keseimbangan hak dan kewajiban.

Hasil olahan data sebaran dari responden yang ditetapkan untuk mengisi kuestionaire sebagai berikut

:Tabel 1. Tanggapan responden tentang transparansi dalam kualitas pelayanan

\begin{tabular}{|l|l|l|l|}
\hline No & Transparansi & Jumah & Presentase \\
\hline 1 & Baik & 13 & 28,00 \\
\hline 2 & Cukup baik & 15 & 32,00 \\
\hline
\end{tabular}




\begin{tabular}{|l|l|l|l|}
\hline 3 & Kurang baik & 19 & 40,00 \\
\hline & Total & 47 & 100 \\
\hline
\end{tabular}

Sumber : data olahan 2016

Pelayanan yang bersifat terbuka, mudah dan dapat diakses oleh semua pihak yang membutuhkan dan disediakan secara memadai serta mudah dimengerti, merupakan point yang sangat penting dalam menilai kualitas pelayanan. Tanggapan responden dari transparansi dalam pelayanan publik di dominasi jawaban kurang baik dengan persentase $40 \%$.

Tabel 2. Tanggapan responden Akuntabilitas dalam kualitas pelayanan publik

\begin{tabular}{|c|c|l|l|}
\hline No & Akuntabilitas & Jumlah & Persentase \\
\hline 1 & Baik & 14 & 30,00 \\
\hline 2 & Cukup baik & 15 & 32,00 \\
\hline 3 & Kurang baik & 18 & 38,00 \\
\hline & Total & 47 & 100 \\
\hline
\end{tabular}

Sumber : data olahan 2016

Kualitas pelayanan public dapat dikatakan efektif bila sudah dapat dipertanggung jawabkan sesuai dengan ketentuan perundang-undangan yang berlaku. Hasil tanggapan responden tentang akuntabilitas dalam pelayanan publik didominasi jawaban kurang baik dengan persentase $38 \%$.

Tabel 3. Tanggapan responden tentang kondisional dalam kualitas pelayanan publik

\begin{tabular}{|c|c|l|l|}
\hline No & Kondisional & Jumlah & Persentase \\
\hline 1 & Baik & 15 & 32,00 \\
\hline 2 & Cukup baik & 19 & 40,00 \\
\hline 3 & Kurang baik & 13 & 28,00 \\
\hline & Total & 47 & 100 \\
\hline
\end{tabular}

Sumber :data olahan 2016

Kualitas pelayanan dapat dikatakan efektif apabila pelayanan disesuaikan dengan kondisi dan kemampuan pemberi dan penerima layanan dengan tetap berpegang kepada prinsip efektifitas dan efesiensi. Tanggapan responden tentang kondisional dalam pelayanan publik didominasi jawaban cukup baik dengan persentase $40 \%$.

Tabel 4. Tanggapan responden tentang partisipatif dalam kualitas pelayanan publik

\begin{tabular}{|c|c|l|l|}
\hline No & Partisipatif & Jumlah & Persentase \\
\hline 1 & Baik & 10 & 21,00 \\
\hline 2 & Cukup baik & 20 & 43,00 \\
\hline 3 & Kurang baik & 17 & 36,00 \\
\hline & Total & 47 & 100 \\
\hline
\end{tabular}

Sumber: data olahan 2016

Kualitas pelayanan dapat dikatakan berhasil apabila pelayanan dapat mendorong peran serta masyarakat dengan memberikan aspirasi, kebutuhan dan harapan masyarakat. Tanggapan responden tentang partisipatif dalam pelayanan didominasi jawaban cukup baik dengan persentase $43 \%$.

Tabel 5. Tanggapan responden tentang kesamaan hak dalam kualitas pelayanan public.

\begin{tabular}{|c|c|l|l|}
\hline No & Kesamaan hak & Jumlah & Persentase \\
\hline 1 & Baik & 9 & 19,00 \\
\hline
\end{tabular}




\begin{tabular}{|l|c|l|l|}
\hline 2 & Cukup baik & 22 & 47,00 \\
\hline 3 & Kurang baik & 16 & 34,00 \\
\hline & Total & 47 & 100 \\
\hline
\end{tabular}

Sumber : data olahan 2016

Kualitas pelayanan public dapat dikatakan berhasil apabila pelayanan tidak melakukan diskriminasi dilihat dari aspek apapun juga,khususnya suku, ras, agama, golongan dan status social. Tanggapan responden tentang kesamaan hak dalam pelayanan public didominasi jawaban cukup baik dengan persentase $22 \%$.

Tabel 6.Tanggapan responden tentang keseimbangan hak dan kewajiban dalam kualitas pelayanan publik

\begin{tabular}{|c|c|l|l|}
\hline No & Keseimbangan hak dan kewajiban & Jumlah & Persentase \\
\hline 1 & Baik & 9 & 19,00 \\
\hline 2 & Cukup baik & 23 & 48,00 \\
\hline 3 & Kurang baik & 15 & 33,00 \\
\hline & Total & 47 & 100 \\
\hline
\end{tabular}

Sumber : data olahan 2016

Kualitas pelayanan public dapat dikatakan berhasil apabila dalam memberikan pelayanan sudah mempertimbangkan aspek keadilan antara pemberi dan penerima layanan public.Tanggapan responden tentang keseimbangan hak dan kewajiban dalam pelayanan publik didominasi jawaban cukup baik dengan persentase $23 \%$.

Tabel 7. Rekapitulasi Tanggapan responden tentang kualitas pelayanan publik

\begin{tabular}{|l|l|l|l|l|l|}
\hline No & Indikator & Baik & Cukup baik & $\begin{array}{l}\text { Kurang } \\
\text { baik }\end{array}$ & $\begin{array}{l}\text { Jumlah } \\
\text { Persentase }\end{array}$ \\
\hline 1 & Transparansi & 13 & 15 & 19 & $\begin{array}{l}47 \\
(100)\end{array}$ \\
\hline 2 & Akuntabilitas & 14 & 15 & 18 & $\begin{array}{l}47 \\
(100)\end{array}$ \\
\hline 3 & Kondisional & 15 & 19 & 13 & $\begin{array}{l}47 \\
(100)\end{array}$ \\
\hline 4 & Partisipatif & 10 & 20 & 17 & $\begin{array}{l}47 \\
(100)\end{array}$ \\
\hline 5 & Kesamaan hak & 9 & 22 & 16 & $\begin{array}{l}47 \\
(100)\end{array}$ \\
\hline 6 & $\begin{array}{l}\text { Keseimbangan hak } \\
\text { dan kewajiban }\end{array}$ & 9 & 23 & 15 & $\begin{array}{l}47 \\
(100)\end{array}$ \\
\hline & $\begin{array}{l}\text { Jumlah } \\
\text { Rata-rata }\end{array}$ & 70 & 144 & 98 & $\begin{array}{l}312 \\
47\end{array}$ \\
\hline
\end{tabular}

Dari rekapitulasi tabel diketahui bahwa hasil penelitian dengan judul kualitas pelayanan public di kantor camat tenayan raya kota pekanbaru adalah didominsi jawaban cukup baik dengan jumlah 144 dan rata-rata 19.

Kualitas pelayanan public yang prima tercermin dari pengaplikasian nilai-nilai : 
1. Transparansi

2. Akuntabilitas

3. Kondisional

4. Partisipatif

5. Kesamaan hak

6. Kesimbangan hak dan kewajiban.

Disadari atau tidak setiap warga selalu berhubungan dengan aktivitas birokrasi pemerintah, sehinggah keberadaannya menjadi suatu yang tidak bisa ditawar-tawar lagi. Pelayanan birokrasi akan menyentuh keberbagai segi kehidupan msyarakat, demikian luasnya cakupan pelayanan masyarakat yang harus dilaksanakan pemerintah maka mau tidak mau pemerintah harus berupaya semaksimal mungkin untuk memenuhi kebutuhan masyaraat akan layanan public. Fungsi pelayanan yang dijalankan oleh pemerintah, seperti yang dikemukakan oleh Rasyid (1997) bahwa: tujuan utama dibentuknya pemerintah adalah untuk menjaga suatu system ketertiban didalam mana masyarakat bisa menjalani kehidupan secara wajar. Kelambanan pelayanan birokrasi tidak hanya disebabkan oleh kurang baiknya cara pelayanan tingkat bawah, factor lain juga mempengaruhi belum baiknya kualitas pelayanan antara lain adalah prinsip dari organisasi pemerintah yang berorintasi kepada pelaksanaan dan pertanggungjawaban formal saja, tanpa mempertimbangkan aspek kualitas. Birokrasi pemerintah pada tingkat tertentu harus menjalankan semangat melayani kepentingan masyarakat sebagai dasar dari motivasi mereka bekerja dibidang pemerintahan, serta memiliki komitmen pengabdian pelayanan untuk memberikan yang terbaik kepada masyarakat. Dari pemaparan di atas menunjukan bahwa kualitas pelayanan public sangat penting untuk memberikan kepuasan kepada masyarakat dan fungsi harus dijalankan oleh pemerintah sebagai abdi masyarakat.

Dari hasil penelitian yang telah dilaksanakan di kantor camat tenayan raya kota pekanbaru yang menjadi kendala atau hambatan dalam meningatkan kualitas pelayanan public adalah keseimbangan hak dan kewajiban yang berkaitan dengan pelayanan yang mempertimbangkan aspek keadi;an antara pemebri dan enerima layanan public, serta factor kesamaan hak yang berkaitan dengan pelayanan tidak melakukan diskriminasi dilihat dari aspek apapun khususnya suku, ras,agama, golongan dan status social. Apabila kedua factor ini dapat berjalan dengan baik maka kualitas pelayanan public khususnya di kantor camat tenayan raya kota pekanbaru.

\section{KESIMPULAN}

1. Kualitas pelayanan public pada kantor camat tenayan raya masih cukup baik

2. Adapun hambatan dalam kualitas pelayanan public adalah keseimbangan hak dan kewajiban.

\section{SARAN}

1. Kualitas pelayanan public pada kantor camat tenayan raya kota pekanbaru perlu ditingkatkan lagi dengan menerapkan prinsip pelayanan prima.

2. Aparatur pemerintahan kecamatan perlu meningkatkan sumber daya manusia sehingggah pelayanan prima dan kualitas pelayanan dapat berjalan dengan baik. 


\section{DAFTAR PUSTAKA}

[1]. Hesel Tangkilisa dan Nogi.2005 Manajemen Publik .Penerbit Raja Grafindo Jakarta

[2]. Monir , 2011 Manajemen Perkantoran Jakarta

[3]. Moenir, H.A.S, 2011, Manajemen Pelayanan Umum di Indonesia, Bumi Aksara, Jakarta

[4]. Napitupulu Paimin, 2009, Pelayanan Publik \& Customer Satisfaction, Alumni, Bandung

[5]. Osborne David dan Gaebler Ted, 2011, Mewirausahakan Birokrasi: Mentransformasi Semangat Wirausaha ke Dalam Sektor Publik (penerjemah Abdul Rosyid), Pustaka Binaman Pressindo, Jakarta

[6]. Osborne David dan Plastik Peter, 2010, Memangkas Birokrasi: Lima Strategi Menuju Pemerintahan Wirausaha (penerjemah Abdul Rosyid), PPM, Jakarta

[7]. Saputra, T. (2016). Pengaruh Motivasi Kerja Terhadap Disiplin Kerja Pegawai Pada Dinas Pemuda Dan Olahraga Provinsi Riau. Jurnal Niara, 8(2), 50-60.

[8]. Siagian SP, 2002, “Organisasi Kepemimpinan dan Prilaku Administrasi”, Gunung Agung, Jakarta

[9]. Sahya,Anggara, 2012 Pengantar Managemen. Rineka Cipta Jakarta

[10]. The Liang Gie, 2011 Filsafat administrasi, Jakarta: Gunung Agung 